\title{
General Practitioner Use of Generically Substitutable Inhaler Devices and the Impact of Training on Device Mastery and Maintenance of Correct Inhaler Technique
}

\author{
Biljana Cvetkovski (D) Charlotte Hespe - Rachel Tan • \\ Vicky Kritikos · Elizabeth Azzi - Sinthia Bosnic-Anticevich
}

Received: July 15, 2020 / Published online: October 10, 2020

(C) The Author(s) 2020

\begin{abstract}
Introduction: Generic substitution of inhaler devices is a relatively new phenomenon. The best patient outcomes associated with generic substitution occur when prescribers obtain consent from their patients to prescribe a generic inhaler and also teach their patient how to correctly use the new device. To date, no prospective observational study has assessed the level of training required for general practitioners (GPs) to demonstrate correct inhaler technique using two dry powder inhaler devices delivering fixed-dose combination budesonide/formoterol therapy. This study aims to
\end{abstract}

Digital Features To view digital features for this article go to https://doi.org/10.6084/m9.figshare.12933002.

Electronic supplementary material The online version of this article (https://doi.org/10.1007/s41030020-00131-8) contains supplementary material, which is available to authorized users.

B. Cvetkovski $(\bowtie) \cdot$ R. Tan · V. Kritikos · E. Azzi ·

S. Bosnic-Anticevich

Quality Use of Respiratory Medicine Group,

Woolcock Institute of Medical Research, University

of Sydney, Sydney, Australia

e-mail: biljana.cvetkovski@sydney.edu.au

C. Hespe

School of Medicine, The University of Notre Dame

Australia, Sydney, Australia

S. Bosnic-Anticevich

Sydney Local Health District, Sydney, Australia
(1) determine the level of training required for GPs to master and maintain correct IT when using two different dry powder inhalers that are able to be substituted in clinical practice and (2) determine the number and types of errors made by GPs on each device and inhaler device preference at each training visit.

Method: A randomized, parallel-group crossover study design was used to compare the inhaler technique of participants with a Spiromax ${ }^{\circledR}$ placebo device and a Turbuhaler ${ }^{\circledR}$ placebo device. This study consisted of two visits with each participant over a period of $4 \pm 1$ weeks (visit 1 and visit 2). A total of six levels of assessment and five levels of training were implemented as required. Level 1 , no instruction; level 2, following use of written instruction; level 3, following viewing of instructional video; level 4, expert tuition from the researcher; level 5/level 6, repeats of expert tuition from the researcher when required. Participants progressed through each level and stopped at the point at which they demonstrated device mastery. At each level, trained researchers assessed the inhaler technique of the participants. Participants were also surveyed about their previous inhaler use and training.

Results: In total, 228 GPs participated in this study by demonstrating their ability to use a Turbuhaler $^{\circledR}$ and a Spiromax ${ }^{\circledR}$ device. There was no significant difference between the proportion of participants who demonstrated device mastery with the Turbuhaler ${ }^{\circledR}$ compared with 
the Spiromax ${ }^{\circledR}$ at level 1, (no instruction), (119/ $228(52 \%)$ versus $131 / 228$ (57\%), respectively, $n=228, p=0.323$ (McNemar's test of paired data). All but one participant had demonstrated correct inhaler technique for both devices by level 3(instructional video). There was a significant difference between the proportion of participants who demonstrated maintenance of device mastery with the Turbuhaler ${ }^{\circledR}$ compared with the Spiromax ${ }^{\circledR}$ at visit 2, level $1(127 / 177$ (72\%) versus $151 / 177$ (85\%) respectively, $p=0.003$; McNemar's test of paired data). All but two participants achieved device mastery by level 3, visit 2. More participants reported previous training with the Turbuhaler ${ }^{\circledR}$ than with Spiromax ${ }^{\circledR}$.

Discussion: This study demonstrates that GPs are able to equally demonstrate correct use of the Turbuhaler ${ }^{\circledR}$ and Spiromax ${ }^{\circledR}$ devices, even though most had not received training on a Spiromax ${ }^{\circledR}$ device prior to this study. The significance of being able to demonstrate correct technique on these two devices equally has ramifications on practice and supported generic substitution of inhaler devices at the point of prescribing, as the most impactful measure a GP can take to ensure effective use of inhaled medicine is the correct demonstration of inhaler technique.

Keywords: Asthma; COPD; Inhaler technique; General practitioners; Physicians; Primary care; Training

\section{Key Summary Points}

Successful generic inhaler substitution requires GPs to obtain consent from their patients to switch inhaler devices AND to demonstrate correct technique to their patients.

GPs have experienced limitations with demonstrating the correct inhaler technique in the past.

This study demonstrates that GPs are equally likely to be able to demonstrate correct inhaler technique with generic and standard inhaler devices.

\section{DIGITAL FEATURES}

This article is published with digital features to facilitate understanding of the article to view digital features for this article go to https://doi. org/10.6084/m9.figshare.12933002.

\section{INTRODUCTION}

Inhaled medicines are the mainstay of pharmacological treatment in asthma and COPD, with tailored treatment for individuals available for a wide selection of inhaler devices [1, 2]. With increased pressure on healthcare budgets and the concurrent expiration of the patent protection of established inhaled treatments, several generic substitutes delivered by devices different from those of the original branded options were developed but were not immediately available due to the difficulty of demonstrating bio-equivalence in practice [3]. Generic substitutes are products that contain the same active substance and quantity as the original branded medicines, and are able to demonstrate bio-equivalence $[4,5]$. For inhaled medicines, demonstrating bio-equivalence is not straightforward as performance of the therapeutic substance is dependent on the formulation, delivery device, and correct use of the device, which is susceptible to the greatest variability $[3,6]$. Therefore, regulatory bodies have come to accept demonstration of 'therapeutic equivalence' as a suitable alternative to bio-equivalence, meaning that the delivery of the same drug via the same route of administration and in the same dose as the original branded option must yield an equivalent dose [4]. The fundamental proviso of this determination is that the two inhaler devices used to deliver the therapeutic substance are being used correctly [7].

While the health economic benefits to individuals and societies associated with generic substitutes are widely accepted [8, 9], ongoing debate surrounds the impact on respiratory health outcomes. While some feel that generic substitution will cause reduced adherence due to patient confusion and dislike of physical attributes of a new inhaler device $[3,10,11]$, patients who have switched appear to be 
equally non-adherent to their generic medicines as to their branded options [8]. It is widely agreed that if generic substitution is to occur, the best outcomes require the prescriber to obtain consent from the patient and demonstrate correct inhaler technique of the generic inhaler device $[3,8,12,13]$. Although substitution can also occur within the pharmacy at the point of dispensing [14], the success of generic substitution of inhalers is dependent on the prescriber obtaining consent and their ability to be able to demonstrate its correct use $[3,13]$.

Poor inhaler technique (IT) has been a major problem in managing chronic respiratory conditions for decades [2, 15-23]. It compromises disease control $[22,24]$ and is associated with an increase in the economic burden of disease management [3]; yet incorrect inhaler use continues to remain an issue in clinical practice [25]. Global experts stress the importance of inhaler technique in the management of chronic respiratory disease [6] and the updated Australian Asthma Management Guidelines and the Global Initiative for Asthma (GINA) Strategy identify inhaler technique as one of the core targets for assessment and intervention for people with poorly controlled disease $[7,8,26]$. Given that approximately $50 \%$ of people with asthma in Australia do not have well-controlled disease [27] and up to $80 \%$ have poor inhaler technique [16], it highlights the importance/ need for prescribers to be actively engaged in IT training, including those inhalers for which there are generic substitutions [27, 28]. Health care professional (HCP) delivery of IT education can take as little as $2 \mathrm{~min}$ [29], however, it is essential that patients' IT is assessed and education repeated over time [30]. Most importantly, the HCPs need to have practical knowledge of how to use the inhalers in order to be able to be proficient in the delivery of IT themselves [30].

While there is much evidence that HCPs are key stakeholders in ensuring correct IT in their patients, their ability and willingness to train patients in the use of inhalers is not ideal $[6,9,31,32]$. Research consistently shows HCPs seldom receive formal training in the use of inhalers [31] and lack the basic knowledge and technical skills to teach (different) inhaler techniques [33, 34]. It has been demonstrated that in some cases, only $15 \%$ of HCPs are able to demonstrate correct IT [33]. The paradigm 'If you don't know, you can't teach' rings true with IT, with patients rarely receiving training in the use of inhalers, despite the emphasis on IT education within the current management guidelines [35, 36].

While the literature has highlighted examples of HCPs not being able to master correct IT, it is important to remember that some inhalers are easier to use than others [1], skills can be transferrable between inhalers of a similar nature [37], and that some steps are more critical than others in optimizing disease control [16]. With these factors in consideration, we need to gain an insight and better understanding of prescribers' skills with the use of newer inhaler devices that are available for generic substitution. Although there are a limited number of inhaler devices that can be substituted for asthma and COPD on the Australian market [38], to date, no prospective observational study has assessed the level of training required for general practitioners (GPs) to demonstrate correct inhaler technique using two devices delivering fixed-dose combination budesonide/formoterol therapy, i.e., the newer generic inhaler device Spiromax ${ }^{\circledR}$ and the established inhaler device Turbuhaler ${ }^{\circledR}$ in the general practice setting $[39,40]$. The Turbuhaler $^{\circledR}$ and Spiromax ${ }^{\circledR}$ both deliver equivalent doses of budesonide/formoterol in multidose, dry powder inhalers, with powder reservoirs from which unit doses are measured $[37,41,42]$ and are registered on the Therapeutic Goods Administration register as being "Brand Equivalent", meaning that these brands may be interchanged without differences in clinical effect [43]. The Turbuhaler ${ }^{\circledR}$ and Spiro$\max ^{\circledR}$ generic substitution is arguably of significant importance at this point in time, not only because fixed-dose combination therapy is frequently prescribed as GINA step 3 and above $[35,44]$, but also when we consider the recent shift in asthma management guidelines, with the introduction of budesonide/formoterol as GINA step 1 therapy for patients with mild asthma [26]. Hence, the ability of GPs to use 
these devices will potentially have an impact on a large proportion of people with asthma in particular.

The aims of this study are: (1) to determine the level of training required for GPs to master and maintain correct IT when using two different dry powder inhalers that are able to be substituted in clinical practice and (2) to determine the number and types of errors made by GPs on each device and inhaler device preference at each training visit.

\section{METHODS}

\section{Study Design and Subjects}

This study was a multicenter, randomized, unblinded, cross-over study and registered as a clinical trial on the Australia and New Zealand Clinical Trials Registry (ACTRN12618001478202). This study was approved by the University of Sydney (2017/ 872) and Notre Dame University (018109S) Human Ethics Committees.

The sampling frame was GPs who are registered and currently practicing as general medical practitioners in NSW. Primary Health Networks (PHNs) within the Sydney metropolitan region were approached to facilitate with distribution of recruitment material. Flyers and advertisements were placed in newsletters and at GP educational events. Snowball recruiting was also encouraged. GPs who were interested in participating were asked to contact the research team via telephone, fax, or e-mail and a researcher then scheduled an appointment to screen for eligibility, complete enrolment, and conduct the study. Appointments took between 10 and $15 \mathrm{~min}$.

GPs were eligible for inclusion into this study if they fulfilled the following criteria: They were a registered, practicing GP in the state of NSW, Australia; were willing and able to comply with the study protocol for the duration of the study and provided verbal informed consent. Potential participants were excluded if they had asthma or COPD or used an inhaler themselves. GPs who were not eligible to participate were provided with inhaler technique education on the Spiromax ${ }^{\circledR}$ and Turbuhaler ${ }^{\circledR}$.

\section{Study Devices and Inhaler Technique}

Participants were required to demonstrate use of a Spiromax ${ }^{\circledR}$ placebo device and a Turbuhaler ${ }^{\circledR}$ placebo device. Placebo devices were requested from the manufacturers of both Turbuhaler ${ }^{\circledR}$ and Spiromax ${ }^{\circledR}$ devices and were supplied as standard placebo inhalers, i.e., empty Turbuhaler $^{\circledR}$ and drug-free lactose containing Spiromax ${ }^{\circledR}$. It was not possible to confirm from the manufacturer why one placebo device was supplied as empty and the other as drug-free lactose containing. It can only be noted that the use of these placebo devices delivers an experience that mimics that of a device containing an active ingredient used by patients in real life. That is, when a patient uses a Turbuhaler ${ }^{\circledR}$, there is a lack of sensation of drug delivered and when Spiromax ${ }^{\circledR}$ is used, there is the sensation of lactose delivery in the mouth [45-49].

The ability of participants to demonstrate correct IT was assessed against IT checklists [39]. These checklists categorize errors into those associated with dose preparation, positioning, inhalation, or general knowledge of device use (Appendix A in ESM).

\section{Study Procedures}

A randomized, parallel-group cross-over study design (Fig. 1) was used to compare the IT of participants with a Spiromax ${ }^{\circledR}$ placebo device and a Turbuhaler ${ }^{\circledR}$ placebo device. This study consisted of two visits with each participant over a period of $4 \pm 1$ weeks (visit 1 and visit 2 ). At the beginning of each visit, data regarding history of inhaler use were collected. At visit 1, participants were randomly assigned to demonstrate their ability to use either Spiro$\max ^{\circledR}$ first followed by Turbuhaler ${ }^{\circledR}$ or Turbuhaler $^{\circledR}$ first followed by Spiromax ${ }^{\circledR}$. Device mastery was assessed by a trained researcher observing the way in which the participant used the devices, against the above-mentioned checklists [39]. Device mastery was defined as the ability to use the device without performing 


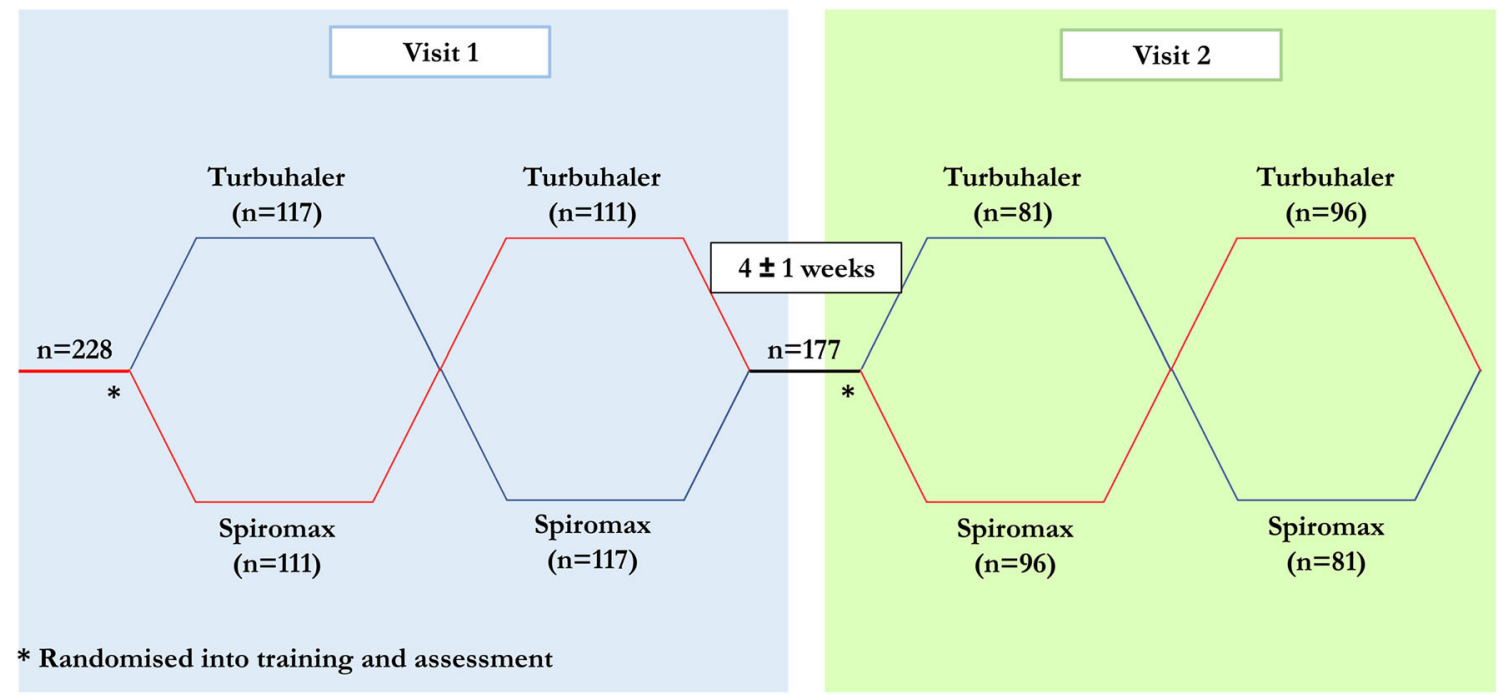

Fig. 1 Overall study design

any errors as observed by the trained researcher assessor. Device maintenance was defined as the ability to use the device at visit 2 without performing any errors (level 1, Fig. 2), without the need to undergo any training during this visit.

At visit 1, participants were randomly assigned to either Spiromax ${ }^{\circledR}$, training followed by Turbuhaler ${ }^{\circledR}$ training or Turbuhaler ${ }^{\circledR}$ training followed by Spiromax ${ }^{\circledR}$ training, in a crossover stage design. Training consisted of five consecutive steps until device mastery was achieved. At visit 2, which commenced $4 \pm 1$ week after visit 1 , participants undertook the same training procedure.

A total of six levels of assessment and five of training were implemented as required (Fig. 2) (Appendix B in ESM) [39]. Level 1, intuitive use (no training); level 2, following use of written instruction; level 3, following viewing of instructional video; level 4, expert tuition from the researcher; level 5/level 6, repeats of expert tuition from the researcher when required. Participants progressed through each level and stopped at the point at which they demonstrated device mastery. At each level, trained researchers assess the IT of participants. The number and type of individual handling errors observed were recorded in the Research Electronic Data Capture (REDCap) system, a secure web application for building and managing online surveys and databases.
After device mastery was achieved, participants were asked to report on the device they preferred based on the Patient Satisfaction and Preference Questionnaire (PASAPQ), Part II Q15 (Appendix C in ESM), which is a single question on device preference extracted from a multiitem validated questionnaire on device satisfaction and preference [50].

\section{Sample Size and Data Analysis}

Data were analyzed using IBM SPSS Version 26.0 (IBM Corporation, Armonk, N1Y). The primary outcome was device mastery at level 1 , visit 1 , i.e., intuitive use of the device. Secondary outcomes included the ability to maintain device use at visit 2; achievement of device mastery at level 1 , and the number of steps required to achieve device mastery; number and types of errors made, and the inhaler preferred by participants at each visit.

In order to detect a minimum statistically significant difference $(0.23)$ on the primary outcome variable (proportion of participants who achieved device mastery at visit 1 between the Spiromax $^{\circledR}$ and Turbuhaler ${ }^{\circledR}$, Power 0.9, with a McNemar's test of equality of paired proportions with a 0.050 two-sided significance level at a minimum, a minimum sample size of 115 pairs was required [39]. 


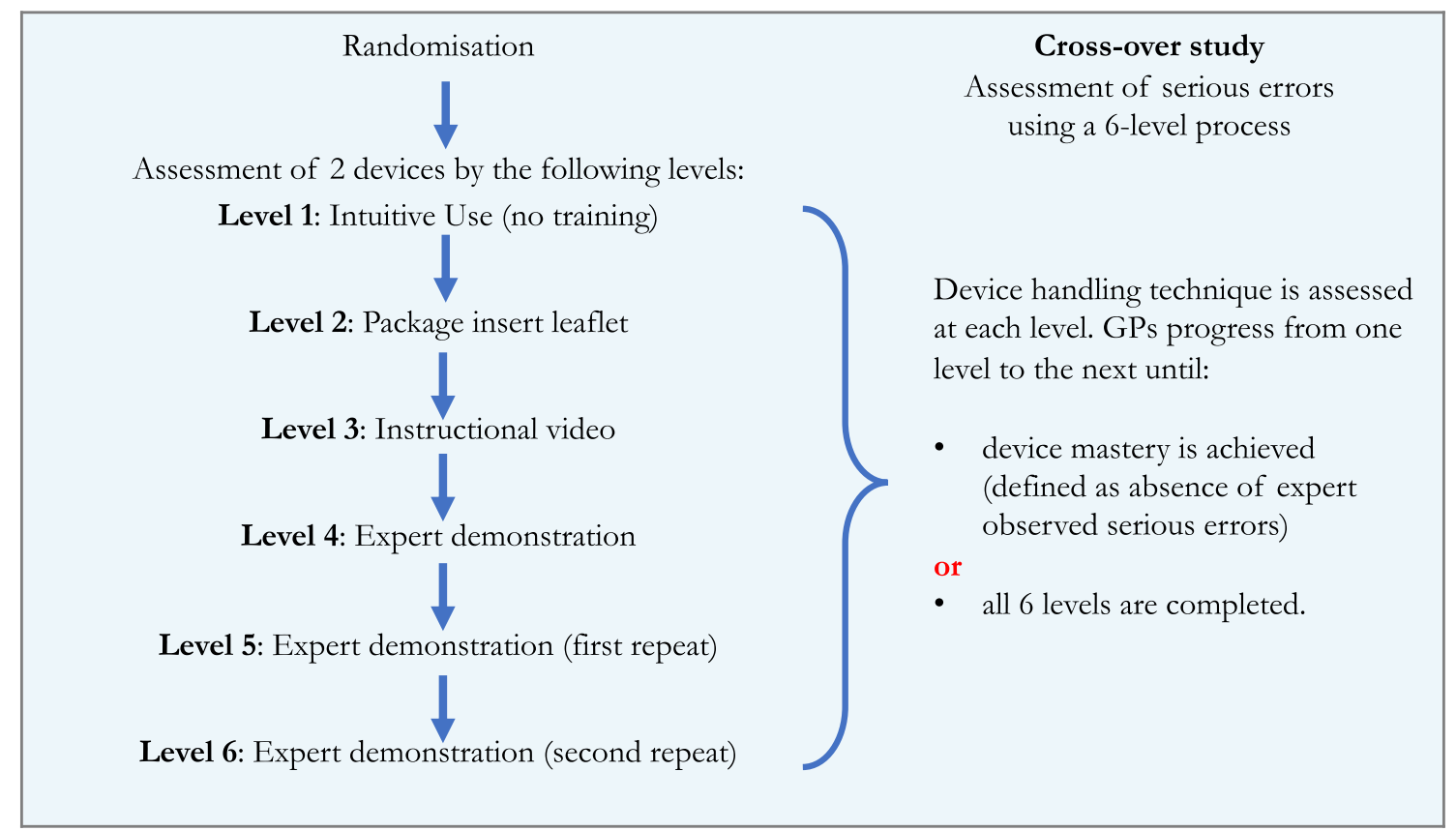

Fig. 2 Inhaler technique assessment and training process. Visit 2 was conducted 4 weeks $( \pm 1$ week) after visit 1 , and identical procedures were repeated

The McNemar's test was used to compare the proportion of subjects achieving mastery of IT between the two devices. The Chi-square test was used to compare the proportion of participants achieving device mastery stratified by the order of randomization and the mean/median number of levels required to achieve device mastery between the two devices, respectively. For all analyses where a $p$ value is provided, statistical significance was set at 0.05 . Summary statistics collected at each visit included: number of levels required to achieve device mastery, number and type of assessor-observed errors (total of errors made at all steps), and device preference. Continuous variables (including age and number of levels taken to achieve device mastery) were summarized by reporting their mean along with their standard deviations. Categorical variables were reported as frequencies and percentage proportions. In particular, device mastery (yes/no) was expressed as cumulative number and percentage of participants achieving device mastery by each training step, unless otherwise stated. Participant demographic and baseline characteristics were summarized using descriptive statistics.

\section{RESULTS}

\section{Participant Demographics and Device Use History}

The study was conducted between August 2018 and May 2019. A total of 246 participants were recruited into this study; of these 228 (44\% male, mean age $46 \pm 13$ years) met the eligibility criteria and were enrolled in the study (Table 1). Of these, 177 participants were available for follow-up at visit 2: and there was a dropout rate of 51/228 (22\%).

A significantly higher proportion of GPs indicated having previously received training on the Turbuhaler ${ }^{\circledR}$ prior to visit 1 compared to those having previously received training on the $\operatorname{Spiromax}^{\circledR}(61.5$ vs. $9.6 \%$, respectively, $n=228$, Chi-squared analysis, $p<0.05$ ).

\section{Primary Outcome: Device Mastery at Visit 1, Level 1}

There was no statistically significant difference between the proportion of participants who 
Table 1 Demographic characteristics for participants at visit 1

\begin{tabular}{|c|c|c|c|}
\hline & $\begin{array}{l}\text { Spiromax } \\
\text { first } \\
(n=111)\end{array}$ & $\begin{array}{l}\text { Turbuhaler } \\
\text { first } \\
(n=117)\end{array}$ & $\begin{array}{l}\text { All } \\
\text { participants } \\
(n=228)\end{array}$ \\
\hline Age (years, mean (SD)) & $45.4(12.7)$ & $45.8(12.8)$ & $45.6(12.7)$ \\
\hline Sex (male, $n(\%))$ & $51(45.9)$ & $50(42.7)$ & $101(44.3)$ \\
\hline $\begin{array}{l}\text { Participant had received training in the use of the Spiromax }{ }^{\circledR} \text { prior to } \\
\text { visit } 1(n, \%)\end{array}$ & $9(14.3)$ & $4(5.5)$ & $13(9.6)^{*}$ \\
\hline $\begin{array}{l}\text { Participant had received training in the use of the Turbuhaler }{ }^{\circledR} \text { prior to } \\
\text { visit } 1(n, \%)\end{array}$ & $38(60.3)$ & $45(62.5)$ & $83(61.5)^{*}$ \\
\hline
\end{tabular}

${ }^{*}$ Statistically significant (Chi-square test, $p<0.05$ )

demonstrated device mastery with the Turbuhaler ${ }^{\circledR}$ compared with the Spiromax $^{\circledR}$ at level $1(119 / 228 \quad(52 \%)$ versus $131 / 228 \quad(57 \%)$, respectively, $n=228, p=0.323$; McNemar's test of paired data). All but two participants achieved device mastery by level 3 instruction on the Turbuhaler $^{\circledR}$ and the Spiromax $^{\circledR}$ (Table 2).

There was a statistically significant higher proportion of participants who demonstrated device mastery with the Spiromax ${ }^{\circledR}$ at level 2 overall (irrespective of randomization order) (Table 2) and at level 2 when it was the randomized to be the second device used (Table 3 ) compared with the proportion of participants who demonstrated device mastery with the Turbuhaler ${ }^{\circledR}$.

\section{Secondary Outcome: Maintaining Device Mastery at Visit 2, Level 1}

There was a statistically significant difference between the proportion of participants who demonstrated maintenance of device mastery with the Turbuhaler $^{\circledR}$ compared with the Spiromax $^{\circledR}$ at visit 2, level $1(127 / 177(72 \%)$ versus 151/177 (85\%) respectively, $p=0.003$; McNemar's test of paired data). All but two participants achieved device mastery by level 3, visit 2. (Table 4 and 5).

Figure 3 shows the proportion of participants demonstrating mastery over time at each visit and at each level of assessment.

Table 2 Participants achieving device mastery at visit 1 , irrespective of randomization order $(n=228)$

\begin{tabular}{llll}
\hline Training level & \multicolumn{2}{l}{ Irrespective of randomization order } \\
\cline { 2 - 4 } & $\begin{array}{l}\text { Turbuhaler } \\
(\boldsymbol{n}=\mathbf{2 2 8})\end{array}$ & $\begin{array}{l}\text { Spiromax } \\
(\boldsymbol{n}=\mathbf{2 2 8})\end{array}$ & $\boldsymbol{p}$ value* $^{\circledR}$ \\
\hline 1. Intuitive use (no training) & $119(52)$ & $131(57)$ & 0.323 \\
2. Patient information leaflet & $202(89)$ & $215(94)$ & 0.007 \\
3. Instructional video & $225(99)$ & $225(99)$ & 1.000 \\
\hline
\end{tabular}

Data are expressed as cumulative $n(\%)$ of participants maintaining/achieving device mastery by each level. Device mastery was defined as the ability to demonstrate inhaler use without assessor-observed errors. Levels 4-6 are not displayed, as no significant difference was detected between the devices at these steps *McNemar test 
Table 3 Participants achieving device mastery at visit 1 , relative to randomization order $(n=228)$

\begin{tabular}{|c|c|c|c|c|c|c|}
\hline \multirow[t]{2}{*}{ Training level } & \multicolumn{3}{|c|}{ First randomized device } & \multicolumn{3}{|c|}{ Second randomized device } \\
\hline & $\begin{array}{l}\text { Turbuhaler }^{\circledR} \\
(n=117)(\%)\end{array}$ & $\begin{array}{l}\text { Spiromax } \\
(n=111)(\%)\end{array}$ & $p$ value $\dagger$ & $\begin{array}{l}\text { Turbuhaler }^{\circledR} \\
(n=111)(\%)\end{array}$ & $\begin{array}{l}\text { Spiromax }^{\circledR} \\
(n=117)(\%)\end{array}$ & $p$ value $^{\dagger}$ \\
\hline 1. Intuitive use (no training) & $58(50)$ & $57(51)$ & 0.788 & $61(55)$ & $74(63)$ & 0.203 \\
\hline 2. Patient information leaflet & $105(90)$ & $101(91)$ & 0.750 & $97(87)$ & $114(97)$ & 0.004 \\
\hline 3. Instructional video & $115(98)$ & $109(98)$ & 0.932 & $110(99)$ & $116(99)$ & 0.317 \\
\hline
\end{tabular}

Data are expressed as cumulative $n(\%)$ of participants maintaining/achieving device mastery by each level. Device mastery was defined as the ability to demonstrate inhaler use without assessor-observed errors. Levels 4-6 are not displayed, as no significant difference was detected between the devices at these steps

$\dagger$ Chi-square test

\section{Secondary Outcome: Number and Types of Errors Made}

The most common error made on the Turbuhaler $^{\circledR}$ was a positioning error where the "Inhaler is not held upright when a dose is prepared", performed incorrectly on $32 \%$ of occasions during visit 1 . The most common errors on the Spiromax ${ }^{\circledR}$ were the "inhaler is not held up right when the dose is prepared" and "vigorous shaking before or after dose preparation" steps, both performed incorrectly on $20 \%$ of occasions during visit 1 (Table 6). Results for rates of errors at all steps are available in the Supplement Table 1.

\section{Secondary Outcome: Participants' Preferences for Inhaler}

At visit 1, 223 participants completed question 15 of the PASAPQ PART II. Spiromax ${ }^{\circledR}$ was the preferred device by $41 \%$ of participants compared to $34 \%$ who stated that Turbuhaler ${ }^{\circledR}$ was their preferred device; $25 \%$ of participants reported no preference (Fig. 4).

At visit 2 , all participants $(n=177)$ completed question 15 of the PASAPQ PART II. Spiromax $^{\circledR}$ was the preferred device by $50 \%$ of participants compared to $32 \%$ who stated that Turbuhaler ${ }^{\circledR}$ was their preferred device; $18 \%$ of participants reported no preference (Fig. 4).

Table 4 Participants maintaining and achieving device mastery at visit 2 , irrespective of randomization order $(n=177)$

\begin{tabular}{llll}
\hline Training level & \multicolumn{2}{l}{ Irrespective of randomization order } \\
\cline { 2 - 4 } & $\begin{array}{l}\text { Turbuhaler } \\
(\boldsymbol{n}=\mathbf{1 7 7})(\%)\end{array}$ & $\begin{array}{l}\text { Spiromax } \\
(\boldsymbol{n}=\mathbf{1 7 7})(\%)\end{array}$ & $\boldsymbol{p}$ value* $^{\left.{ }^{(}\right)}$ \\
\hline $\begin{array}{l}\text { Maintenance of device mastery } \\
\text { 1. Intuitive use (no training) }\end{array}$ & $127(72)$ & $151(85)$ & 0.003 \\
$\begin{array}{l}\text { Achievement of device mastery } \\
\text { 2. Patient information leaflet }\end{array}$ & $167(94)$ & $175(99)$ & 0.065 \\
3. Instructional video & $177(100)$ & $175(99)$ & - \\
\hline
\end{tabular}

Data are expressed as cumulative $n$ (\%) of participants maintaining/achieving device mastery by each level. Device mastery was defined as the ability to demonstrate inhaler use without assessor-observed errors. Levels 4-6 are not displayed, as no significant difference was detected between the devices at these steps

${ }^{*} \mathrm{McNemar}$ test 
Table 5 Participants maintaining and achieving device mastery at visit 2, relative to randomization order $(n=177)$

\begin{tabular}{|c|c|c|c|c|c|c|}
\hline \multirow[t]{2}{*}{ Training level } & \multicolumn{3}{|c|}{ First randomized device } & \multicolumn{3}{|c|}{ Second randomized device } \\
\hline & $\begin{array}{l}\text { Turbuhaler } \\
(n=81)(\%)\end{array}$ & $\begin{array}{l}\text { Spiromax }^{\circledR} \\
(n=96)(\%)\end{array}$ & $p$ value $^{\dagger}$ & $\begin{array}{l}\text { Turbuhaler } \\
(n=96)(\%)\end{array}$ & $\begin{array}{l}\text { Spiromax }^{\circledR} \\
(n=81)(\%)\end{array}$ & $p$ value $e^{\dagger}$ \\
\hline \multicolumn{7}{|l|}{ Maintenance of device mastery } \\
\hline 1. Intuitive use (no training) & $61(75)$ & $80(83)$ & 0.186 & $66(69)$ & $71(88)$ & 0.003 \\
\hline \multicolumn{7}{|l|}{ Achievement of device mastery } \\
\hline 2. Patient information leaflet & $76(94)$ & $94(98)$ & 0.164 & $91(95)$ & $81(100)$ & 0.037 \\
\hline 3. Instructional video & $81(100)$ & $94(98)$ & 0.191 & $96(100)$ & $81(100)$ & - \\
\hline
\end{tabular}

Data are expressed as cumulative $n$ (\%) of participants maintaining/achieving device mastery by each level. Device mastery was defined as the ability to demonstrate inhaler use without assessor-observed errors. Levels 4-6 are not displayed, as no significant difference was detected between the devices at these steps

$\dagger$ Chi-square test

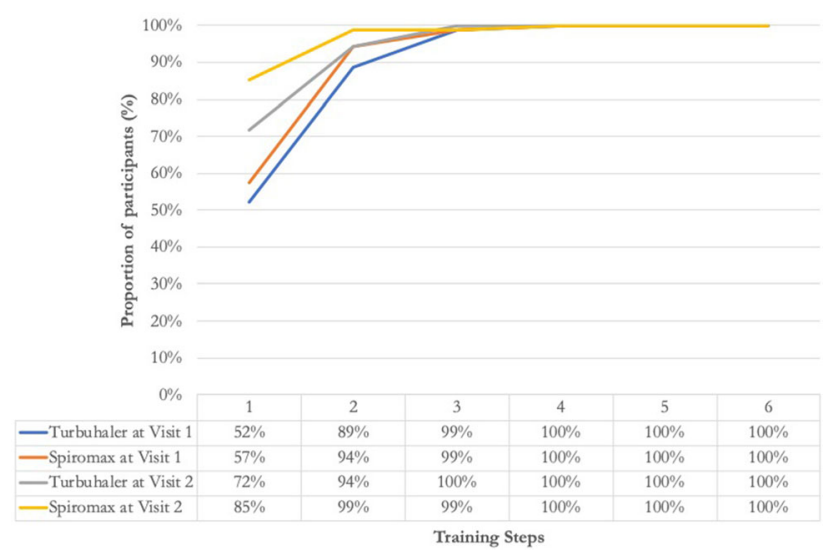

Fig. 3 Proportion of participants achieving and maintaining device mastery over the study period. The chart shows the cumulative proportion (\%) of participants demonstrating correct inhaler technique with the two study

\section{DISCUSSION}

This multicenter, randomized, un-blinded, cross-over study, to our knowledge, is the first to compare the level of training required for GPs to master and maintain correct IT when using two dry powder inhaler devices that can be substituted in clinical practice-the Spiromax ${ }^{\circledR}$ and the Turbuhaler ${ }^{\circledR}$. The study further determined the number and types of errors made by GPs on each inhaler device and inhaler device devices at each step during the study visits. Total number of participants: visit $1, n=228$ and visit $2, n=177$

preference at each training visit. Our study revealed several key findings: (1) despite the fact that GPs were less likely to have previously received training on the newer generic Spiro$\max ^{\circledR}$, they were equally able to demonstrate device mastery with the Spiromax ${ }^{\circledR}$ and Turbuhaler $^{\circledR}$, on which a majority of GPs had received previous training; (2) maintaining device mastery by GPs was more likely with Spiromax $^{\circledR}$ than Turbuhaler ${ }^{\circledR}$; (3) GPs were more likely to make more errors with 
Table 6 Most common device errors at each visit

\begin{tabular}{|c|c|c|c|c|c|}
\hline \multicolumn{3}{|l|}{ Turbuhaler $^{\circledR}$} & \multicolumn{3}{|l|}{ Spiromax ${ }^{\circledR}$} \\
\hline Type of error & Description & $n(\%)^{*}$ & Type of error & Description & $n(\%)^{*}$ \\
\hline \multicolumn{6}{|l|}{$\begin{array}{l}\text { Visit } 1 \\
\quad(n=228)\end{array}$} \\
\hline Position & $\begin{array}{l}\text { Inhaler is not held upright when a dose is prepared } \\
\text { (upright means mouthpiece skywards } \pm 45^{\circ} \text { ) } \\
\text { throughout dose preparation }\end{array}$ & $73(32 \%)$ & Position & $\begin{array}{l}\text { Inhaler is not held upright } \\
\text { after dose preparation } \\
\left( \pm 90^{\circ} \text { is OK }\right)\end{array}$ & ${ }^{45}(20 \%)$ \\
\hline $\begin{array}{l}\text { Dose } \\
\text { preparation }\end{array}$ & $\begin{array}{l}\text { Dose preparation: not twisting the base as far as possible, } \\
\text { until it clicks and not turning it back to the original } \\
\text { position }\end{array}$ & $30(13 \%)$ & $\begin{array}{l}\text { Dose } \\
\text { preparation }\end{array}$ & $\begin{array}{l}\text { Vigorous shaking before and } \\
\text { after dose preparation }\end{array}$ & ${ }^{45}(20 \%)$ \\
\hline $\begin{array}{l}\text { Inhalation } \\
\text { maneuver }\end{array}$ & Inhalation is not as fast as possible (from the start) & $33(14 \%)$ & $\begin{array}{l}\text { Inhalation } \\
\text { maneuver }\end{array}$ & $\begin{array}{l}\text { Inhalation is not as fast as } \\
\text { possible (from the start) }\end{array}$ & ${ }^{38}(17 \%)$ \\
\hline \multicolumn{6}{|c|}{ Visit $2(n=177)$} \\
\hline Position & $\begin{array}{l}\text { Inhaler is not held upright when a dose is prepared } \\
\text { (upright means mouthpiece skywards } \pm 45^{\circ} \text { ) } \\
\text { throughout dose preparation }\end{array}$ & $17(10 \%)$ & Position & $\begin{array}{l}\text { Inhaler is not held upright } \\
\text { after dose preparation } \\
\left( \pm 90^{\circ} \text { is OK }\right)\end{array}$ & $14(8 \%)$ \\
\hline $\begin{array}{l}\text { Dose } \\
\text { preparation }\end{array}$ & $\begin{array}{l}\text { Dose preparation: not twisting the base as far as possible, } \\
\text { until it clicks, and not turning it back to the original } \\
\text { position }\end{array}$ & $14(8 \%)$ & $\begin{array}{l}\text { Dose } \\
\quad \text { preparation }\end{array}$ & $\begin{array}{l}\text { Vigorous shaking before and } \\
\text { after dose preparation }\end{array}$ & $9(5 \%)$ \\
\hline $\begin{array}{l}\text { Inhalation } \\
\text { maneuver }\end{array}$ & Inhalation is not as fast as possible (from the start) & $14(8 \%)$ & $\begin{array}{l}\text { Inhalation } \\
\text { maneuver }\end{array}$ & $\begin{array}{l}\text { Inhalation is not as fast as } \\
\text { possible (from the start) }\end{array}$ & $8(5 \%)$ \\
\hline
\end{tabular}

${ }^{*}$ Number and $\%$ of participants who made the error

Turbuhaler $^{\circledR}$ than Spiromax ${ }^{\circledR} ;$ (4) the most common error made on the Turbuhaler ${ }^{\circledR}$ was not holding the inhaler upright during dose preparation and on the Spiromax ${ }^{\circledR}$ it was not holding the inhaler upright after dose preparation as well as vigorous shaking of the inhaler before or after dose preparation and (5) Spiro$\max ^{\circledR}$ was the preferred inhaler device at each training visit.

This study demonstrated that there was no difference in the proportion of GPs who could demonstrate device mastery with Turbuhaler $^{\circledR}$ compared with the Spiromax ${ }^{\circledR}$. Considering that the majority of GPs had reported having previously received education/instruction on the use of the Turbuhaler ${ }^{\circledR}$ and a minority on the use of the Spiromax ${ }^{\circledR}$, it suggests that device-naïve GPs are likely to be able to intuitively use the Spiromax ${ }^{\circledR}$ device at the point of prescribing and to demonstrate correct IT to their patients when generic substitution is required. This finding has significant implications for everyday practice in the general practice setting, especially given the overwhelming number of inhalers available on the market. GPs are the first HCP in the chain of asthma management; they initiate medication treatment, are in a position to change therapy (and devices), and are the HCP that most people with respiratory illness turn to $[16,17]$. A history of poor IT among HCPs has cast doubt on the feasibility of generic substitution of inhaler devices, given that successful substitution requires GPs to obtain patient consent as well as demonstrate correct device technique [13]. However, this research goes some way to alleviating the potential risks of generic substitutions in the case of budesonide/formoterol, (i.e., of Turbuhaler ${ }^{\circledR}$ and Spiromax $\left.{ }^{\circledR}\right)$. Given the paradigm shift in asthma management with budesonide/formoterol as needed therapy at GINA step 1 for mild asthma [26] and the potential for millions of people with asthma to be affected by this particular inhaler generic substitution, the reassurance of device equipoise between these two distinctly different devices in terms of IT in real-life general practice (despite differences in education received) is particularly reassuring.

Consistent with previous research among HCPs and patients, this study among practicing GPs confirmed that maintaining device mastery is problematic [7, 45-48]. It can be argued that $100 \%$ of prescribers should be maintaining 


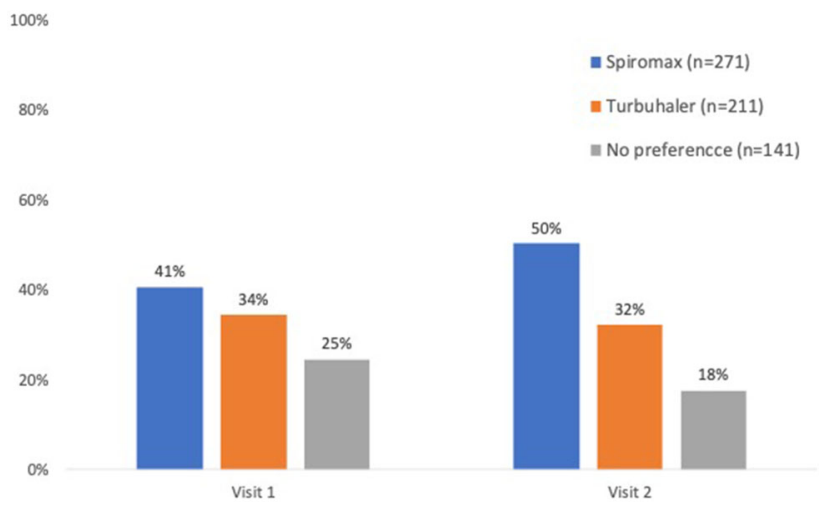

Fig. 4 Participants' preferred device at the completion of visits 1 and 2

correct IT after training, however despite this, we have found that maintaining correct IT was more likely with the Spiromax ${ }^{\circledR}$ than with the Turbuhaler $^{\circledR}$. These findings are in line with health care profession students who are naive to these dry powder inhaler devices ${ }^{\circledR}$ [39] with the implication that GPs may require less frequent "refreshment"/upskilling on the use of certain devices compared to others [51]. While frequent educational interventions do improve longterm maintenance of IT [51], the reality is that from the GPs perspective, there needs to be a prioritization of this aspect of asthma management. Research has clearly shown that IT is more than a physical skill and motivation plays an important role [17]. Whether GPs have the time and inclination to devote the time to IT and the complex counselling that is probably needed around IT, adherence, and the quality use of medicines $[52,53]$ is a question that continues to remain unanswered.

From a technical perspective, it was found that GPs were more likely to make a greater number of IT errors with the Turbuhaler ${ }^{\circledR}$ when compared to the Spiromax ${ }^{\circledR}$. The errors identified with Turbuhaler ${ }^{\circledR}$ use were "critical errors" that have been shown to be linked to poor asthma control and increased exacerbation rate among asthma patients [16, 54, 55]. Although the Spiromax ${ }^{\circledR}$ had not been evaluated in the above studies as it was not available at the time, the types of errors performed incorrectly with its use are of a similar nature to those critical errors made with Turbuhaler $^{\circledR}$ use, namely positioning, dose preparation, and inhalation maneuver. The consistency in the types of errors performed incorrectly between devices is understandable given that dry powder inhalers frequently have the same features [37]. However, it also raises the question about whether errors are individual user rather than device related. This similarity can mean that there is also a knowledge transfer between devices [37] and this partially played out in this study with GPs performing better with the Spiromax ${ }^{\circledR}$, once they had been trained with the Turbuhaler $^{\circledR}$, but not visa a versa. Despite the fundamental mechanisms underpinning this finding, there is a clear message that comes out of it, i.e., considering the wide range of dry powder inhalers and the concern among HCPs with regards to switching between inhalers [56], focusing education on these commonly performed errors may help to improve mastery of IT across a range of inhalers.

It is also interesting to delve more deeply into the nature of the errors made. By exploring these errors, there is a suggestion that perhaps these GPs do not have a full understanding of the concept of dry powder inhalers (DPIs), which have a number of core characteristics. The most common error made on the Turbuhaler ${ }^{\circledR}$ was not holding the inhaler upright during dose preparation and on Spiromax ${ }^{\circledR}$ it was not holding the inhaler upright after dose preparation as well as shaking the inhaler vigorously. Both at visit 1 and visit 2, the proportion of participants who made a breathing maneuver error was similar, which is understandable because the breathing maneuver is 
the most similar step between these two devices. However, there was a difference in the proportion who made the other errors and this can be explained by the fact that these two devices look and operate very differently. Interestingly, the shaking of the Spiromax ${ }^{\circledR}$ once again shows that participants did not really have an understanding of what a DPI is and because it visually resembles a pressurized metered-dose inhaler (pMDI), in the absence of education, it was being treated like a pMDI. This result is different from a study where student HCPs who have no experience prescribing medicines were assessed in their ability to correctly use and maintain correct technique with Turbuhaler $^{\circledR}$ and Spiromax ${ }^{\circledR}$ [39], where shaking of the Spiromax was not a common error observed. Considering that our study involved experienced prescribers and that DPIs are prescribed in equal frequency to pMDIs for the delivery of ICS [38], it is no surprise that this confusion arose and that perhaps training of IT should focus on steps that are technically specific to each device, once again, highlighting the knowledge transfer that happens form the use of one device to another, and that fact that this is sometimes not a positive transfer of knowledge.

In this study, Spiromax ${ }^{\circledR}$ was the preferred inhaler device at the conclusion of each training visit, with preference increasing during the second visit. One possible reason for this increased preference at the second visit was the increased likelihood of being able to demonstrate its correct use in the first instance (level 1). Dry powder inhalers, including Turbuhaler ${ }^{\circledR}$ and Spiromax ${ }^{\circledR}$, are traditionally easier to use than pMDIs [1] and Spiromax has been identified as a preferred inhaler due to its ease of use in a study with patients comparing use of dry powder inhalers [57]. While the GPs in this study expressed a preference for Spiromax ${ }^{\circledR}$, in practice, patient preference for a device, the device itself, the physician's own experience with the device, and several other factors impact their choice of prescription $[1,11,58]$. Similarly, cost to the patient is in consideration when prescribing a device, hence the importance of ensuring a 'generic' device is able to be mastered by prescribers who bear significant responsibility in ensuring correct device technique during generic substitution $[58,59]$.

A limitation of this study was interrater variability as previously identified in similar IT assessment research [16]. To minimize interrater variability, assessors received standardized training, used the same resources, and assessed each other prior to fieldwork. They were also shown the same examples of incorrect device use and asked to provide their independent evaluations and further training was undertaken when there were discrepancies in the assessments among assessors, but this cannot completely eliminate possibility of inter-rater and intra-rater variability. Further, as with most research, there is participant bias in that only GPs who were interested in IT agreed to participate or alternatively, those who felt that they needed training participated. We are not able to determine the potential impact of this potential bias. Despite these biases, there were no significant outliers present in the results demonstrating consistency in the assessment process. However, several steps such as inhalation force cannot be measured objectively through observation and this study could be strengthen if objective measures could be conducted.

A potential bias in this study is associated with the fact that we were supplied with empty Turbuhaler $^{\circledR}$ devices versus Spiromax ${ }^{\circledR}$ devices containing lactose. The presentation of these two devices was consistent with the way in which each of the two manufacturers supply their "placebo" inhalers. We believe that this does in fact mimic the sensations experienced by patients when using these medication-filled devices [45, 47-49], however do recognize that it may be a source of bias in this study. The presence of lactose in the Spiromax $^{\circledR}$ does equate to a feedback mechanism associated with use of this device. Feedback mechanisms provide users with a sign that the device has been used, however not necessarily that the device has been used correctly. While the primary aim of this study was to evaluate intuitive IT, which is not necessarily impacted by feedback mechanisms, it is foreseeable that this feedback mechanism could influence participant preference. Research indicates that feedback mechanisms can impact user device 
preference in both a positive and negative way $[3,45,60,61]$. "Taste" (such as that associated with the deposition of lactose in the mouth) is a polarizing feature that can sometimes be associated with a decreased preference for a device but can also be a feature associated with increased preference due to the feedback feature [47]. With the development of novel "smart" inhalers, digital feedback, such as audio and visual feedback, is becoming a key feature [62]. In light of this, the results relating to participant preference for a device should be interpreted with caution.

Future studies assessing feasibility of generic substitution of inhaler devices should go beyond assessing the GP's ability to demonstrate correct IT. There are several other factors associated with generic substitution and IT that were not addressed within this study. Investigations into how GPs teach and assess patients' IT, their ability to identify errors, and counsel on other issues associated with substitution such as feel/taste/delivery/confusion/packaging needs to be conducted. Further to this, it is essential to investigate the relationship between the GP's ability to use inhalers and its effect on patient IT. Similarly, investigating the role of the pharmacist in obtaining consent for generic substation, identifying IT errors, and teaching correct IT would be valuable to distribute the responsibility between both HCPs involved in prescribing and dispensing. Further investigations also need to evaluate whether correcting IT may lead to greater adherence and evaluation of whether a dose adjustment may be required [63, 64].

\section{CONCLUSIONS}

GPs can equally demonstrate correct technique with both Turbuhaler ${ }^{\circledR}$ and Spiromax ${ }^{\circledR}$ devices although most were Spiromax ${ }^{\circledR}$-naïve with only a minority reporting a history of receiving training on Spiromax ${ }^{\circledR}$ instruction in the past. Substitution of either device during prescribing can be supported with GPs demonstrating correct device use, once patient consent for substitution has occurred. However, the use of inhalers and knowledge around the difference between different inhalers remains an issue, regardless of the extent of training previously received.

\section{ACKNOWLEDGEMENTS}

All authors would like to acknowledge the general practitioners who voluntarily provided their time to be a part of this study.

Funding. This study was sponsored by TEVA Pty Ltd. No funding or sponsorship was received for the publication of this study.

Authorship. All named authors meet the International Committee of Medical Journal Editors (ICMJE) criteria for authorship for this article, take responsibility for the integrity of the work as a whole, and have given their approval for this version to be published.

Disclosures. Biljana Cvetkovski, Rachel Tan, and Elizabeth Azzi have no conflicts of interest. Charlotte Hespe has received research grants from Amgen and Sanofi. She has received speaker and education advisory honorarium from Pfizer, GSK, and Novartis. Vicky Kritikos has received honoraria from AstraZeneca, GlaxoSmithKline, and Pfizer. Sinthia BosnicAnticevich is a member of the Teva Pharmaceuticals Devices International Key Experts Panel, has received research support from Research in Real Life, has received lecture fees and payment for developing educational presentations from Teva and Mundipharma; and has received Honoria from AstraZeneca, Boehringer Ingelheim, GlaxoSmithKline, for her contribution to advisory boards/key international expert forum.

Compliance with Ethics Guidelines. This study was approved by the Sydney University Human Ethics Committee and The University of Notre Dame Human Ethics Committee and was performed in accordance with the Helsinki Declaration of 1964, and its later amendments. All subjects provided informed consent to participate in the study. 
Data Availability. Anonymous data are stored within a University of Sydney repository and are available from the authors upon written request.

Open Access. This article is licensed under a Creative Commons Attribution-NonCommercial 4.0 International License, which permits any non-commercial use, sharing, adaptation, distribution and reproduction in any medium or format, as long as you give appropriate credit to the original author(s) and the source, provide a link to the Creative Commons licence, and indicate if changes were made. The images or other third party material in this article are included in the article's Creative Commons licence, unless indicated otherwise in a credit line to the material. If material is not included in the article's Creative Commons licence and your intended use is not permitted by statutory regulation or exceeds the permitted use, you will need to obtain permission directly from the copyright holder. To view a copy of this licence, visit http://creativecommons.org/licenses/by$\mathrm{nc} / 4.0 /$.

\section{REFERENCES}

1. Lavorini F, Janson C, Braido F, Stratelis G, Løkke A. What to consider before prescribing inhaled medications: a pragmatic approach for evaluating the current inhaler landscape. Therapeutic Adv Respir Dis. 2019;13:1753466619884532.

2. Sanchis J, Gich I, Pedersen S. Systematic review of errors in inhaler use: has patient technique improved over time? Chest. 2016;150:394-406.

3. Lavorini F, Ninane V, Haughney J, Bjermer L, Molimard M, Dekhuijzen RPN. Switching from branded to generic inhaled medications: potential impact on asthma and COPD. Expert Opin Drug Deliv. 2013;10:1597-602.

4. Administration TTG. Inhalation and nasal spray generic registered medicines Health, D.o., Ed. Australian Government: Canberra, 2019; Vol. V2.1.

5. Birkett DJ. Generics-equal or not? Austr Prescriber. 2003;2003:26.
6. Price D, Summers M, Zanen P. Could interchangeable use of dry powder inhalers affect patients? Int J Clin Pract. 2005;59:3-6.

7. Committee for Medicinal Products for Human Use. European Medicines Agency. mGUIDELINE on the requirements for clinical documentation for orally inhaled products (OIP) including the requirements for demonstration of therapeutic equivalence between two inhaled products for use in the treatment of asthma and chronic obstructive pulmonary disease (COPD) in adults and for use in the treatment of asthma in children and adolescents. London (2009). Available at https://www.ema.europa. eu/en/documents/scientific-guideline/guidelinerequirements-clinical-documentation-orallyinhaled-products-oip-including-requirements_en. pdf. Accessed 1 July 2020.

8. Engelkes M, van Blijderveen JC, Overbeek JA, Kuiper J, Herings RCM, Sturkenboom M, de Jongste JC, Verhamme KMC, Janssens HM. Brand and generic use of inhalation medication and frequency of switching in children and adults: a populationbased cohort study. J Asthma. 2018;55:1086-94.

9. Lewis A, Torvinen S, Dekhuijzen PNR, Chrystyn H, Melani A, Zöllner Y, Kolbe K, Watson AT, Blackney M, Plich A. Budesonide + formoterol delivered via spiromax ${ }^{\circledR}$ for the management of asthma and COPD: the potential impact on unscheduled healthcare costs of improving inhalation technique compared with turbuhaler $^{\circledR}$. Respir Med. 2017;129: 179-88.

10. Capstick TGD, Khachi H, Murphy A, Dancona G, Meynell H, Wilson P. Generic prescribing is not appropriate for inhaled drugs. Pharamceut J. 2015;2015:294.

11. Booth A. Prescribing inhaled therapy in asthma: health professionals' habits and beliefs. J Prescrib Pract. 2020;2:181-6.

12. Doyle S, Lloyd A, Williams A, Chrystyn H, Moffat M, Thomas M, Price D. What happens to patients who have their asthma device switched without their consent? Prim Care Respir J J Gener Pract Airways Group. 2010;19:131-9.

13. Thomas M, Price D, Chrystyn H, Lloyd A, Williams $\mathrm{AE}$, von Ziegenweidt J. Inhaled corticosteroids for asthma: impact of practice level device switching on asthma control. BMC Polm. 2009;9:1.

14. Rigby D. Switching inhaler devices [online].Personal author: Rigby, debbie; source: Ajp: The australian journal of pharmacy, vol. 99, no. 1177, oct 2018: 8-9 document type: Journal article issn: 0311-8002 subject: Lungs-diseases, obstructive; inhalers; pharmacist and patient; patient 
education; medical instruments and apparatus-reliability. Austr J Pharm. 2018;99(8-9):1177.

15. Basheti IA, Qunaibi EA, Hamadi SA, Reddel HK. Inhaler technique training and health-care professionals: effective long-term solution for a current problem. Respir Care. 2014;59:1716-25.

16. Price DB, Román-Rodríguez M, McQueen RB, Bosnic-Anticevich S, Carter V, Gruffydd-Jones K, Haughney J, Henrichsen S, Hutton C, Infantino A, et al. Inhaler errors in the critikal study: type, frequency, and association with asthma outcomes. J Allergy Clin Immunol Pract. 2017;5:1071-81.

17. Ovchinikova L, Smith L, Bosnic-Anticevich S. Inhaler technique maintenance: gaining an understanding from the patient's perspective. J Asthma. 2011;48:616-24.

18. Vargas O, Martinez J, Ibanez M, Pena C, Santamaria $\mathrm{M}$. The use of metered-dose inhalers in hospital environments. J Aerosol Med Pulm Drug Deliv. 2013;26:287-96.

19. Goris S, Tasci S, Elmali F. The effects of training on inhaler technique and quality of life in patients with COPD. J Aerosol Med Pulm Drug Deliv. 2013;26:336-44.

20. García-Cárdenas V, Sabater-Hernández D, GarcíaCorpas JP, Faus MJ, Martínez-Martínez F, Benrimoj SI. Errors in turbuhaler technique in a spanish population of asthmatic patients. Respiratory Care. 2012;57:817.

21. Melani AS, Canessa P, Coloretti I, DeAngelis G, DeTullio R, Del Donno M, Giacobbe R, Scarlato I, Serafini A, Barbato N, et al. Inhaler mishandling is very common in patients with chronic airflow obstruction and long-term home nebuliser use. Respir Med. 2012;106:668-76.

22. Basheti IA, Reddel HK, Armour CL, Bosnic-Anticevich SZ. Improved asthma outcomes with a simple inhaler technique intervention by community pharmacists. J Allergy Clin Immunol. 2007;119: 1537-8.

23. Usmani OS, Lavorini F, Marshall J, Dunlop WCN, Heron L, Farrington E, Dekhuijzen R. Critical inhaler errors in asthma and COPD: a systematic review of impact on health outcomes. Respir Res. 2018;19:10-10.

24. Giraud V, Roche N. Misuse of corticosteroid metered-dose inhaler is associated with decreased asthma stability. Eur Respir J. 2002;19:246-51.

25. Makhinova TW, Gukert BL, Kalvi M, Guirguis L, Pharmacy LM. Checking inhaler technique in the community pharmacy: predictors of critical errors. Pharmacy. 2020;2020:8.

26. Global Initiative for Asthma (GINA). Global strategy for asthma management and prevention. 2020. Available at https://ginasthma.org/wp-content/ uploads/2020/06/GINA-2020-report_20_06_04-1wms.pdf. Accessed 1 July 2020.

27. Reddel H, Sawyer S, Everett WP, Flood VP, Peters JM. Asthma control in australia: a cross-sectional web-based survey in a nationally representative population. Med J Austr 2015;202:492-496.

28. Bosnic-Anticevich S, Kritikos V, Carter V, Yan KY, Armour C, Ryan D, Price D. Lack of asthma and rhinitis control in general practitioner-managed patients prescribed fixed-dose combination therapy in australia. J Asthma. 2017;2017:1-11.

29. Axtell S, Haines S, Fairclough J. Effectiveness of various methods of teaching proper inhaler technique. J Pharm Pract. 2017;30:195-201.

30. Bosnic-Anticevich SZ, Cvetkovski B, Azzi EA, Srour $P$, Tan R, Kritikos V. Identifying critical errors: addressing inhaler technique in the context of asthma management. Pulm Ther. 2018. https://doi. org/10.1007/s41030-018-0051-0.

31. Press VG, Pincavage AT, Pappalardo AA, Baker DC, Conwell WD, Cohen JC, Hoyte FL, Johnson ME, Prochaska $\mathrm{MH}$, Vela $\mathrm{MB}$, et al. The chicago breathe project: a regional approach to improving education on asthma inhalers for resident physicians and minority patients. J Natl Med Assoc. 2010;102: 548-55.

32. Hanania NA, Wittman R, Kesten S, Chapman KR. Medical personnel's knowledge of and ability to use inhaling devices. Metered-dose inhalers, spacing chambers, and breath-actuated dry powder inhalers. Chest. 1994;105:111-6.

33. Plaza V, Sanchis J, Roura P, Molina J, Calle M, Quirce S, Viejo JL, Caballero F, Murio C. Physicians' knowledge of inhaler devices and inhalation techniques remains poor in spain. J Aerosol Med Pulm Drug Deliv. 2012;25:16-22.

34. Karle E, Patel TP, Zweig J, Krvavac A. Understanding the knowledge gap and assessing comfort level among healthcare professionals who provide inhaler education. COPD J Chronic Obstruct Pulmonary Disease. 2020;17:197-204.

35. National Asthma Council Australia. Asthma Management Handbook. 2020. Available at https:// www.asthmahandbook.org.au/. Accessed 28 Sept 2020. 
36. Lung Foundation Australia. The COPD-X Plan: Australian and New Zealand Guidelines for the management of Chronic Obstructive Pulmonary Disease 2020. Available at https://copdx.org.au/wpcontent/uploads/2020/04/COPDX-V2-61-Feb-2020FINAL.pdf. Accessed 28 Sept 2020.

37. Lavorini F, Fontana GA, Usmani OS. New inhaler devices-the good, the bad and the ugly. Respir Int Rev Thoracic Dis. 2014;88:3-15.

38. Lavorini F, Corrigan CJ, Barnes PJ, Dekhuijzen PR, Levy ML, Pedersen S, Roche N, Vincken W, Crompton GK. Retail sales of inhalation devices in european countries: so much for a global policy. Respir Med. 2011;105:1099-103.

39. Bosnic-Anticevich S, Callan C, Chrystyn H, Lavorini F, Nikolaou V, Kritikos V, Dekhuijzen PNR, Roche N, Bjermer L, Rand C, et al. Inhaler technique mastery and maintenance in healthcare professionals trained on different devices. J Asthma. 2018;55:79-88.

40. Canonica GW, Arp J, Keegstra JR, Chrystyn H. Spiromax, a new dry powder inhaler: dose consistency under simulated real-world conditions. J Aerosol Med Pulm Drug Deliv. 2015;28:309-19.

41. Astra Zeneca. Symbicort Turbuhaler ${ }^{\circledR}$ Product Information Doc ID-000377105 v9; 2019.

42. TEVA Pharmaceuticals. Duoresp ${ }^{\circledR}$ Spiromax ${ }^{\circledR}$ Product Information; 2019.

43. Scheme(PBS), P.B. Brand equivalence. 2020. http:// www.pbs.gov.au/info/healthpro/explanatorynotes/section2/section-2-symbols. Accessed 5 June 2020 .

44. Australian Institute of Health and Welfare(AIHW), Ampon R, Reddel HK, Marks GB. Respiratory medication use in Australia 2003-2013: treatment of asthma and COPD. AIHW: Canberra, 2015; vol. Cat. no. ACM 31. 2015.

45. Gillissen A, Gessner C, Hechenbichler K, Herth FJF, Juenemann R, Kanniess F, Kardos P, Lommatzsch M, Schneidereit R, Windisch W. Patient satisfaction and clinical outcomes with budesonide plus formoterol spiromax for asthma and chronic obstructive pulmonary disease: a real-world, observational trial. Respir Int Rev Thoracic Dis. 2019;97:292-301.

46. Canonica GW, Arp J, Keegstra JR, Chrystyn H. Spiromax, a new dry powder inhaler: dose consistency under simulated real-world conditions. J Aerosol Med Pulmonary Drug Deliv. 2015;28: 309-19.

47. Welch M, Nelson HS, Shapiro G, Bensch G, Sokol W, Smith J, Parasuraman B. Comparison of patient preference and ease of teaching inhaler technique for pulmicort turbuhaler ${ }^{\circledR}$ versus pressurized metered-dose inhalers. J Aerosol Med. 2004;17: 129-39.

48. Gioulekas D, Papakosta D, Vordoyianni P, Baloti H, Vamvalis C. A comparison of the clinical efficacy and patient acceptability of terbutaline turbuhaler and salbutamol rotahaler, in adult patients with asthma. Respir Med. 1996;90:205-9.

49. Crompton GK. Dry powder inhalers: advantages and limitations. J Aerosol Med. 1991;4:151-6.

50. Kozma CM, Slaton TL, Monz BU, Hodder R, Reese PR. Development and validation of a patient satisfaction and preference questionnaire for inhalation devices. Treatments Respir Med. 2005;4:41-52.

51. Takemura M, Kobayashi M, Kimura K, Mitsui K, Masui H, Koyama M, Itotani R, Ishitoko M, Suzuki $\mathrm{S}$, Aihara K, et al. Repeated instruction on inhalation technique improves adherence to the therapeutic regimen in asthma. J Asthma. 2010;47: 202-8.

52. Bosnic-Anticevich S, Azzi E, Srour P, Armour C, Rand C. Predicting inhaler technique maintenance: an art or a science? Eur Respir J. 2016;48:PA620.

53. Azzi E, Srour P, Armour C, Rand C, Bosnic-Anticevich S. Practice makes perfect: self-reported adherence a positive marker of inhaler technique maintenance. NPJ Prim Care Respir Med. 2017;27: 29.

54. Barbara SA, Kritikos V, Price DB, Bosnic-Anticevich S. Identifying patients at risk of poor asthma outcomes associated with making inhaler technique errors. J Asthma. 2020;2020:1-12.

55. Lavorini F, Magnan A, Dubus JC, Voshaar T, Corbetta L, Broeders M, Dekhuijzen R, Sanchis J, Viejo $\mathrm{JL}$, Barnes P, et al. Effect of incorrect use of dry powder inhalers on management of patients with asthma and COPD. Respir Med. 2008;102:593-604.

56. Williams AE, Chrystyn H. Survey of pharmacists' attitudes towards interchangeable use of dry powder inhalers. Pharm World Sci. 2007;29:221-7.

57. Sandler N, Holländer J, Långström D, Santtila P, Saukkonen A, Torvinen S. Evaluation of inhaler handling-errors, inhaler perception and preference with spiromax, easyhaler and turbuhaler devices among healthy finnish volunteers: a single site, single visit crossover study (finhaler). BMJ Open Respir Res. 2016;3:e00119.

58. Miravitlles M, Soler-Cataluña JJ, Alcázar B, Viejo JL, García-Río F. Factors affecting the selection of an inhaler device for COPD and the ideal device for 
different patient profiles. Results of epoca delphi consensus. Pulm Pharmacol Ther. 2018;48:97-103.

59. Ampon RD, Reddel HK, Correll PK, Poulos LM, Marks GB. Cost is a major barrier to the use of inhaled corticosteroids for obstructive lung disease. Med J Aust. 2009;191:319-23.

60. Riley J, Krüger P. Optimising inhaler technique in chronic obstructive pulmonary disease: a complex issue. Br J Nurs. 2017;26:391-7.

61. Roche N, Chrystyn H, Lavorini F, Agusti A, Virchow JC, Dekhuijzen PNR, Price D. Effectiveness of inhaler devices in adult asthma and COPD. Respiratory. 2013;1:64-71.
62. Blakey JD, Bender BG, Dima AL, Weinman J, Safioti G, Costello RW. Digital technologies and adherence in respiratory diseases: the road ahead. Eur Respir J. 2018;52:1801147.

63. Price D, Thomas M, Haughney J, Lewis RA, Burden A, von Ziegenweidt J, Chisholm A, Hillyer EV, Corrigan CJ. Real-life comparison of beclometasone dipropionate as an extrafine- or larger-particle formulation for asthma. Respir Med. 2013;107: 987-1000.

64. Postma DS, Roche N, Colice G, Israel E, Martin RJ, van Aalderen WM, Grigg J, Burden A, Hillyer EV, von Ziegenweidt J, et al. Comparing the effectiveness of small-particle versus large-particle inhaled corticosteroid in COPD. Int J Chron Obstruct Pulmon Dis. 2014;9:1163-86. 